\title{
Sentinel-1 Radar Data Assessment to Estimate Crop Water Stress
}

\author{
M. A. El-Shirbeny ${ }^{1 *}$, K. Abutaleb ${ }^{1,2}$ \\ ${ }^{1}$ National Authority for Remote Sensing and Space Sciences (NARSS), Cairo, Egypt \\ ${ }^{2}$ Institute of Soil, Climate and Water, ARC, Pretoria, South Africa \\ Email: ^mshirbeny@yahoo.com,m.elshirbeny@narss.sci.eg
}

How to cite this paper: El-Shirbeny, M.A. and Abutaleb, K. (2017) Sentinel-1 Radar Data Assessment to Estimate Crop Water Stress. World Journal of Engineering and Technology, 5, 47-55. https://doi.org/10.4236/wjet.2017.52B006

Received: January 19, 2017

Accepted: June 26, 2017

Published: June 29, 2017

\begin{abstract}
Water is an important component in agricultural production for both yield quantity and quality. Although all weather conditions are driving factors in the agricultural sector, the precipitation in rainfed agriculture is the most limiting weather parameter. Water deficit may occur continuously over the total growing period or during any particular growth stage of the crop. Optical remote sensing is very useful but, in cloudy days it becomes useless. Radar penetrates the cloud and collects information through the backscattering data. Normalized Difference Vegetation Index (NDVI) was extracted from Landsat 8 satellite data and used to calculate Crop Coefficient (Kc). The FAO-Penman-Monteith equation was used to calculate reference evapotranspiration (ETo). NDVI and Land Surface Temperature (LST) were calculated from satellite data and integrated with air temperature measurements to estimate Crop Water Stress Index (CWSI). Then, both CWSI and potential crop evapotranspiration (ETc) were used to calculate actual evapotranspiration (ETa). Sentinel-1 radar data were calibrated using SNAP software. The relation between backscattering $(\mathrm{dB})$ and CWSI was an inverse relationship and $\mathrm{R}^{2}$ was as high as 0.82 .
\end{abstract}

\section{Keywords}

Sentinel-1, Landsat 8, Backscattering (dB), Crop Water Stress Index (CWSI), Egypt

\section{Introduction}

With a rapidly growing world population, the pressure on limited fresh water resources increases. Agriculture is the largest water consuming sector. It faces competing demands from other sectors, such as the industrial and the domestic sectors. With an increasing population and less water available for agricultural production, the food security for future generations is at stake. The great chal- 
lenge of the agricultural sector is to produce more food from less water, which can be achieved by increasing Crop Water Productivity (CWP) [1].

Limited water is the principal factor responsible for reduced cereal yields globally and especially in Mediterranean environment [2]. The response of crop yield to water stress is different for crop type and climate. Therefore, the values of CWSI should be determined for a particular crop in different climates to be used in irrigation scheduling.

Remote sensing techniques were used and evaluated to estimate ETa and ETc [3]-[11] and predict soil water availability [12] for irrigation water management.

Factors such as water stress, stomata conductivity, heat flux, transpiration and cooling cause plants to close their stomata. As a result, evaporation decreases and the canopy temperature increases, when compared to non-stressed plants [13]. So, monitoring and detecting crop water stress is important to know crop health during the growing season. One way to get an indicator for crop water stress is measuring plant water content; fresh biomass minus dry biomass. This is a very time consuming method, so it is not easily applicable to construct time series of crop water stress. The widely used method was developed by [14] [15], using remote sensing method in the thermal infrared (TIR) spectrum.

The surface temperature and crop water stress are associated for the reason that as a crop transpires, the evaporated water cools the canopy below the air temperature. Moreover, as a crop becomes water stressed, the transpiration will decrease and the crop surface temperatures will then increase sometimes more than the air temperature [16].

Under water stress conditions, plants tend to close their stomata. Therefore, the concept of canopy temperature was implemented to determine plant water status [13]. The empirical relationship for canopy-air temperatures difference (Tc-Ta) versus Vapor Pressure Deficit (VPD) was represented to quantify the crop water stress. [17] found that cotton yield declined when the average CWSI during the season was greater than 0.2 .

[14] developed empirical linear relationships between canopy and air temperature difference $\mathrm{dT}$ (Tc-Ta) and VPD. The lower limit of dT versus VPD indicates that the crop is well watered. Upper limit of dT versus VPD means the crop is not transpiring and dry [13] and [17] [18]. Application of CWSI with satellite-based or aircraft-based measurements of surface temperature is generally applied to full-canopy conditions so that the surface temperature is equal to canopy temperature. Decreased water uptake closes stomata of the leaves resulting in a reduction of the transpiration. The leaf or canopy temperature can be used to quantify plant water stress.

The main aim of this study is to estimate the crop water status through Radar and optical remote sensing data.

\section{Materials and Methods}

\subsection{Study Area Description}

The study area is located in the eastern part of the Nile Delta Figure 1. 


\subsection{Remote Sensing Data}

Landsat 8 image on Jul. 26th, 2016, (path 192/row 030) around 10 a.m. local time with 30 meter ground resolution and Sentinel-1 radar data on Jul. 26th, 2016 with 10 meter ground resolution were used.

\subsection{NDVI and LST Estimation}

Landsat 8 bands 4 and 5 provide red (R) and near-infra red (NIR) measurements and therefore can be used to generate NDVI with the following formula:

$$
\text { NDVI }=(\text { Band } 5-\text { Band } 4) /(\text { Band } 5+\text { Band } 4)
$$

The recorded Digital Numbers (DN) were converted to radiance units (Rad) using the calibration coefficients specific for each band. Band 10 was used to extract LST as follows:

$$
\operatorname{Rad}=0.0003342 * \mathrm{DN}+0.10000
$$

Surface emissivity (Eo) was estimated from NDVI using the empirical equation developed from raw data on NDVI and thermal emissivity [19].

$$
\text { Eo }=0.9932+0.0194 \operatorname{lnNDVI}
$$

The radiant temperature (To) can be calculated from band 10 radiance (Rad 10) using calibration constants $\mathrm{K} 1=774.89$ and $\mathrm{K} 2=1321.08$.

$$
\mathrm{To}=\mathrm{K} 2 / \ln ((\mathrm{K} 1 / \operatorname{Rad} 10)+1)
$$

The resulting temperature (Kelvin) is the satellite radiant temperature of the viewed earth atmosphere system, which is correlated with, but not the same as, the surface (kinetic) temperature. The atmospheric effects and surface thermal

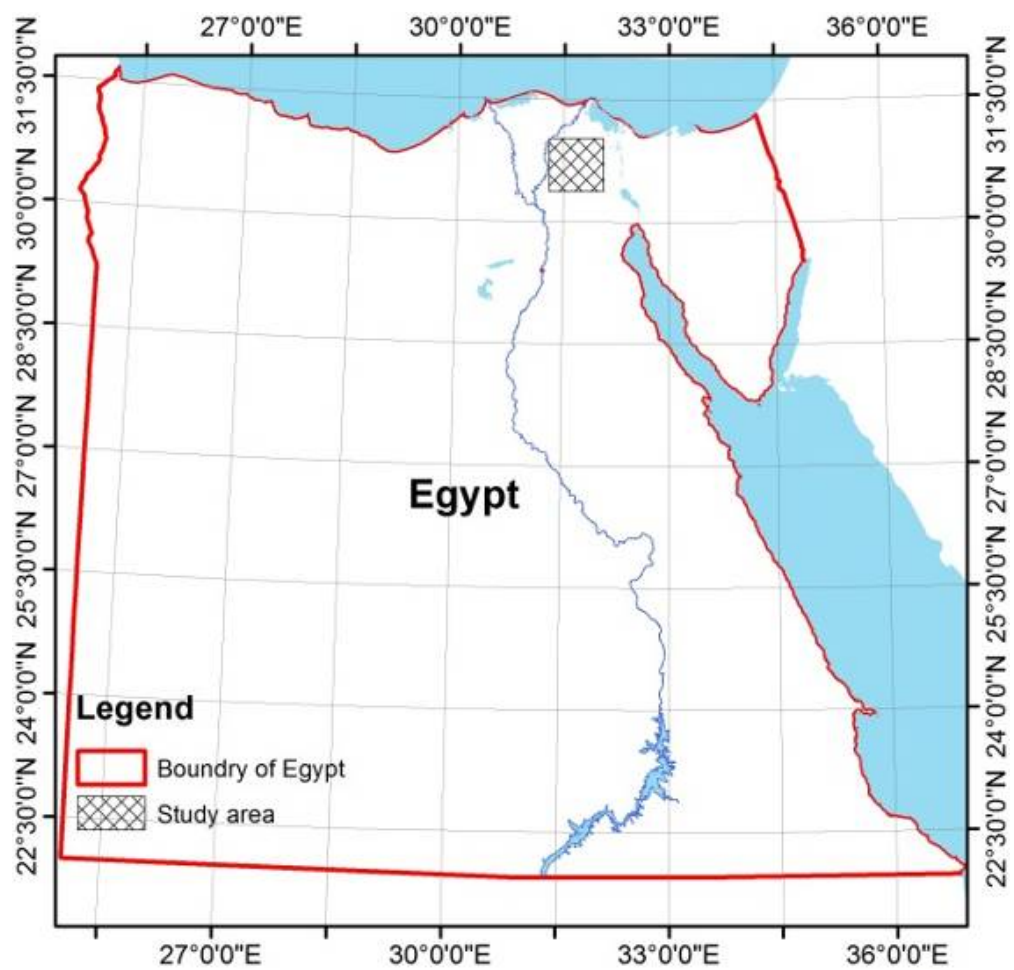

Figure 1. Location map of the study area. 
emissivity have to be considered in order to obtain an accurate estimate of surface temperature from satellite thermal data [20]. LST is calculated from the top of atmosphere radiant temperature (To) and estimated surface emissivity (Eo) as:

$$
\text { LST }=\text { To/Eo }
$$

\subsection{ETa and ETc Estimation}

[15] showed that there is a unique mathematical relationship between CWSI and evapotranspiration from vegetation surface as follows:

$$
\mathrm{ETa}=(1-\mathrm{CWSI}) * \mathrm{ETc}
$$

where ETa is the actual evapotranspiration, ETc is the potential crop evapotranspiration and CWSI is Crop Water Stress Index. CWSI approach was preceded and developed by [14] [15]. They proposed the empirical and theoretical methods to estimate CWSI as follows:

$$
\mathrm{CWSI}=\frac{\Delta \mathrm{T}-\Delta \mathrm{Tm}}{\Delta \mathrm{Tx}-\Delta \mathrm{Tm}}
$$

Where: $\Delta \mathrm{T}$ is the difference between measured surface and air temperature, $\Delta \mathrm{Tm}$ is the difference between minimum surface and air temperature and $\Delta \mathrm{Tx}$ is the difference between maximum surface and air temperature. Since all variables have the same units, CWSI is a dimensionless ratio. The lower limit of dT occurs under non-water-stressed conditions when ET is only limited by atmospheric demand. On the other hand, the upper limit of dT is reached under non-transpiring conditions when ET is stopped due to the lack of water. The values of CWSI are ranged between zero and one where zero indicates no stress and value of one indicates maximum stress.

Many researchers studied the relationship between Kc and NDVI. Similarities between Kc curve and a satellite-derived vegetation index showed potential for modeling a $\mathrm{Kc}$ as a function of the vegetation index [21]. Therefore, the possibility of directly estimating Kc from satellite data was investigated [5] and [22] [23].[5] represented the relation between Kc and NDVI through Equation (8) which calibrated for wheat by [23].

$$
\mathrm{Kc}=\frac{1.2}{\mathrm{NDVI}_{\mathrm{dv}}}\left(\mathrm{NDVI}-\mathrm{NDVI}_{\mathrm{mv}}\right)
$$

where; 1.2 is the maximum $\mathrm{Kc}, \mathrm{NDVI}_{\mathrm{dv}}$ is the difference between minimum and maximum NDVI value for vegetation and $\mathrm{NDVI}_{\mathrm{mv}}$ is the minimum NDVI value for vegetation.

ETo was calculated from meteorological data using the FPM method (Equation (9)) which was derived by [24]. This formula was applied to calculate ETo.

$$
\text { ETo }=\frac{0.408 \Delta\left(\mathrm{R}_{\mathrm{n}}-\mathrm{G}\right)+\gamma \frac{900}{\mathrm{~T}+273} \mathrm{u}_{2}\left(\mathrm{e}_{s}-\mathrm{e}_{a}\right)}{\Delta+\gamma\left(1+0.34 \mathrm{u}_{2}\right)}
$$

Where; ETo, reference evapotranspiration [ $\mathrm{mm} / \mathrm{day}], \mathrm{R}_{\mathrm{n}}$, net radiation at the 
crop surface $\left[\mathrm{MJ} / \mathrm{m}^{2} /\right.$ day], $G$, soil heat flux density $\left[\mathrm{MJ} / \mathrm{m}^{2} /\right.$ day], T, mean daily air temperature at $2 \mathrm{~m}$ height $\left[{ }^{\circ} \mathrm{C}\right], \mathrm{u}_{2}$, wind speed at $2 \mathrm{~m}$ height $[\mathrm{m} / \mathrm{s}], \mathrm{e}_{\mathrm{s}}$, saturation vapour pressure $[\mathrm{kPa}], e_{\mathrm{a}}$, actual vapour pressure $[\mathrm{kPa}], \mathrm{e}_{\mathrm{s}}-\mathrm{e}_{\mathrm{a}}$, saturation vapour pressure deficit $[\mathrm{kPa}], \Delta$, slope vapour pressure curve $\left[\mathrm{kPa} /{ }^{\circ} \mathrm{C}\right], \gamma, \mathrm{psyc}-$ hrometric constant $\left[\mathrm{kPa} /{ }^{\circ} \mathrm{C}\right]$.

Equations (8) and (9) were used to estimate (ETc) as shown in equation (10).

$$
\mathrm{ETc}=\mathrm{ETo}^{*} \mathrm{Kc}
$$

\subsection{Sentinel Data Processing}

The crop and soil water content are indexed by the calibrated radar data of the backscattered VV-polarization data. According to SNAP software help manual, the objective of SAR calibration is to provide imagery in which the pixel values can be directly related to the radar backscatter of the scene. To do this, the application output scaling applied by the processor must be undone and the desired scaling must be applied. Level-1 products provide four calibrations Look Up Tables (LUTs) to produce $\beta 0 \mathrm{i}, \sigma 0 \mathrm{i}$ and $\gamma \mathrm{i}$ or to return to the DN. The LUTs apply a range-dependent gain including the absolute calibration constant. For Ground Range Detected (GRD) products, a constant offset is also applied.

The radiometric calibration is applied by the following equation:

$$
\text { value }(\mathrm{i})=\frac{\left|\mathrm{DN}_{\mathrm{i}}\right|^{2}}{\mathrm{~A}_{\mathrm{i}}{ }^{2}}
$$

where, depending on the selected LUT,

$$
\text { value }(\mathrm{i})=\text { one of } \beta^{0}{ }_{i}, \sigma^{0}{ }_{i} \text { or original } \mathrm{DN}_{\mathrm{i}}
$$$$
\mathrm{A}_{\mathrm{i}}=\text { one of } \beta_{i}^{0}, \sigma^{0}{ }_{i} \text { and } \gamma_{i} \text { or } \operatorname{dn}(\mathrm{i})
$$

The bi-linear interpolation is used for any pixels that fall between points in the LUT.

\section{Results and Discussion}

\subsection{Potential and Actual Evapotranspiration}

ETc was estimated through Equation (10) based on two parameters which are ETo and Kc. [3] and [25] [26] used the FPM method, to estimate ETo based on ground meteorological data to evaluate or to couple with the remotely sensed data. ETo was estimated from ground meteorological data according to the FPM model. ETo value was $6.7 \mathrm{~mm} /$ day.

Many researchers studied the relation between Kc and NDVI [27] [28] [29] [30]. They demonstrated that ET for irrigated agriculture can be estimated by applying empirical data to develop a relationship between the NDVI and Kc. [31] [32] similarly used remote sensing to estimate Kcb. They found that Kcb methods can be transformed to Kc methods by adding an estimate for Ke to Kcb.

The relation between Kc and NDVI is highly correlated where both of them are varying from planting to senescence in the same way. NDVI is calculated from Red and NIR bands, and varying according to crop age, planting density and chlorophyll activity. The results of Kc values varied from 0 to 1.2. 
In the study area, ETc values varied from 0 to $7.8 \mathrm{~mm} /$ day according to land cover type, crop stage and weather conditions as shown in Figure 2.

In arid and semi-arid climates, ET ranges over a large interval depending on water regimes. Moreover, the variation in one weather parameter immediately influences all the other variables that are mutually related. This fact makes it difficult to correctly evaluate the ETa [33]. [34] analyzed the efficiency of three methods based on the FAO-56 Kc approach to estimate ETa for winter wheat under different irrigation treatments under the semi-arid conditions of Morocco. ETa was estimated according to Equation (6). It was affected by the changes in CWSI and ETc. The values of ETa varied from 0 to $6.4 \mathrm{~mm} /$ day. As shown as in Figure 2, the increasing in ETa was observed according to land cover type, crop stage, weather conditions and water stress conditions.

\subsection{The Relation between Sentinel-1 and Landsat 8 Data}

The radar data from the European Space Agency's Sentinel-1A/B Ground Range Detected High Resolution (GRDHR), was used after radiometric and geometric calibration to represent the SAR data. On the other hand, the Landsat 8 data was used to calculate NDVI, LST, CWSI and ETa.

The backscattering data increased according to crop and soil water content. According to Figure 3, the relation between backscattering and NDVI was good and $\mathrm{R}^{2}$ was as high as 0.9 , while the relation between backscattering and LST was an inverse relationship and $\mathrm{R}^{2}$ was as high as 0.82 . The relation between the backscattering and CWSI was an inverse relationship and $\mathrm{R}^{2}$ was 0.82 . On the other hand the relationship between the backscattering and ETa was logarithmic with a high $\mathrm{R}^{2}$ (0.88).
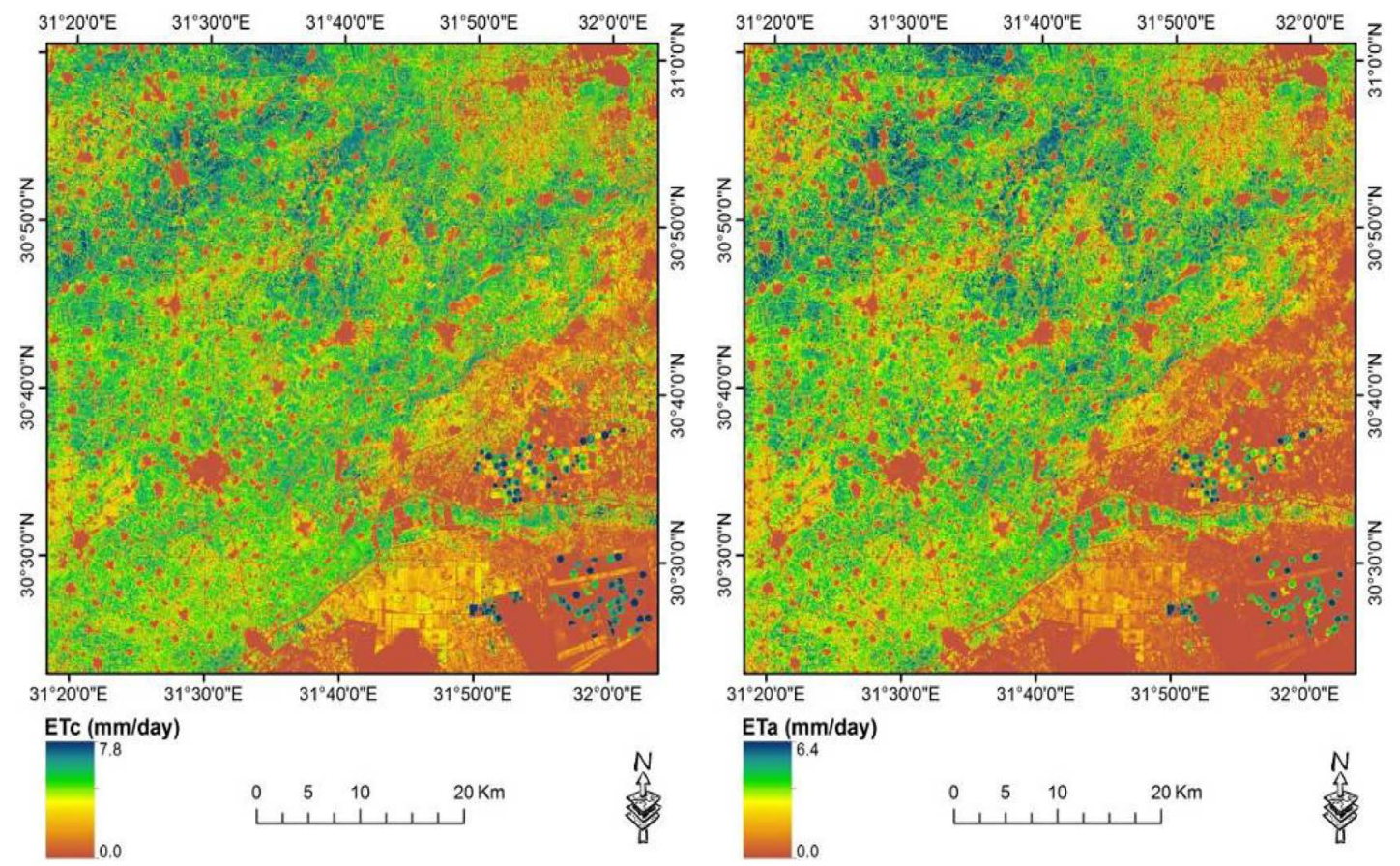

Figure 2. ETc and ETa destrbution ( $\mathrm{mm} /$ day). 

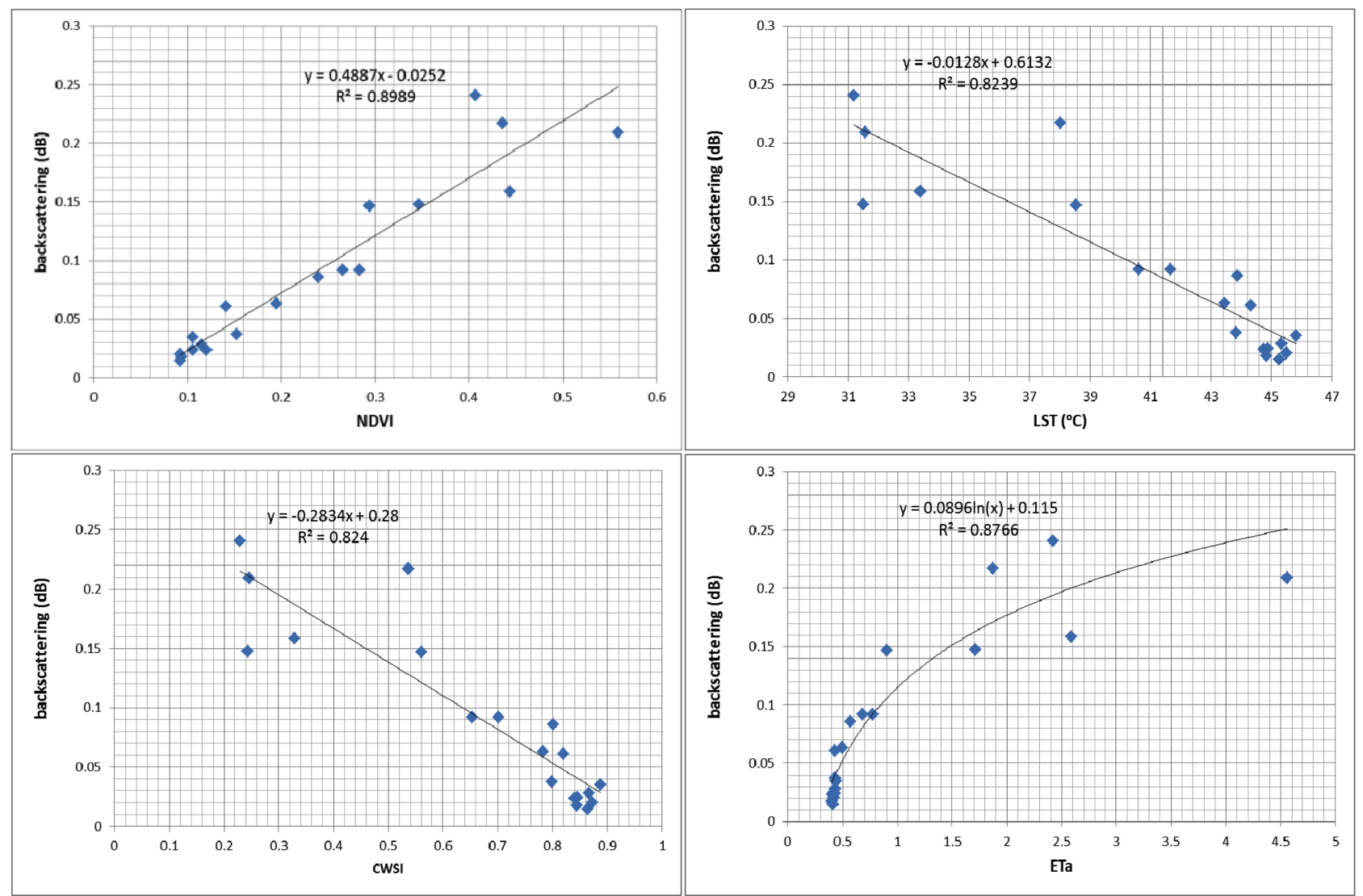

Figure 3. The relation between Backscattering SAR data and NDVI, LST, CWSI and ETa.

\section{Conclusion}

The backscattering $(\mathrm{dB})$ is very effective to qualitative and quantitative crop and soil water content. In the northern part of Egypt during the winter season, the analysis of VH and VV data is very useful in case of cloud coverage status. The relation between radar and optical remote sensing data was strong. Water stress can be estimated using radar data as well as optical data.

\section{References}

[1] Zwart, S.J. and Bastiaanssen, W.G.M. (2004) Review of Measured Crop Water Productivity Values for Irrigated Wheat, Rice, Cotton and Maize. Agricultural Water Management, 69, 115-133. https://doi.org/10.1016/j.agwat.2004.04.007

[2] Acevedo, E.H., Silva, P.C., Silva, H.R. and Solar, B.R. (1999) Wheat Production in Mediterranean Environments, In: Satorre, E.H. and Slafer, G.A. (Eds.), Wheat Ecology and Physiology of Yield Determination. Food Products Press, New York, 295323.

[3] Rwasoka, D.T., Gumindoga, W. and Gwenzi, J. (2011) Estimation of Actual Evapotranspiration Using the Surface Energy Balance System (SEBS) Algorithm in the Upper Manyame Catchment in Zimbabwe. Physics and Chemistry of the Earth, 36, 736-746. https://doi.org/10.1016/j.pce.2011.07.035

[4] Merlin, O., Chirouze, J., Olioso, A., Jarlan, L., Chehbouni, G. and Boulet, G. (2014) An Image-Based Four-Source Surface Energy Balance Model to Estimate Crop Evapotranspiration from Solar Reflectance/Thermal Emission Data (SEB-4S). Agricul- 
tural and Forest Meteorology, 184, 188-203.

https://doi.org/10.1016/j.agrformet.2013.10.002

[5] El-Shirbeny, M.A., Ali, A. and Saleh, N. (2014a) Crop Water Requirements in Egypt Using Remote Sensing Techniques. Journal of Agricultural Chemistry and Environment, 3, 57-65. https://doi.org/10.4236/jacen.2014.32B010

[6] El-Shirbeny, M.A., Aboelghar, M.A., Arafat, S.M. and El-Gindy, A.G.M. (2014) Assessment of the Mutual Impact between Climate and Vegetation Cover Using NOAA-AVHRR and Landsat Data in Egypt. Arabian Journal of Geosciences, 7, 1287-1296. https://doi.org/10.1007/s12517-012-0791-3

[7] El-Shirbeny, M.A., Saleh, N.H. and Ali, A.M. (2014) Estimation of Potential Crop Evapotranspiration Using Remote Sensing Techniques. Proceedings of the 10 th International Conference of AARSE, 460-468.

[8] Hu, G., Jia, L. and Menenti, M. (2015) Comparison of MOD16 and LSA-SAF MSG Evapotranspiration Products over Europe for 2011. Remote Sensing of Environment, 156, 510-526. https://doi.org/10.1016/j.rse.2014.10.017

[9] Tadesse, T., Senay, G.B., Berhan, G., Regassa, T. and Beyen, S. (2015) Evaluating a Satellite-Based Seasonal Evapotranspiration Product and Identifying Its Relationship with other Satellite-Derived Products and Crop Yield: A Case Study for Ethiopia. International Journal of Applied Earth Observation and Geoinformation, 40, 39-54. https://doi.org/10.1016/j.jag.2015.03.006

[10] French, A.N., Hunsaker, D.J. and Thorp, K.R. (2015) Remote Sensing of Evapotranspiration over Cotton Using the TSEB and METRIC Energy Balance Models. Remote Sensing of Environment, 158, 281-294.

https://doi.org/10.1016/j.rse.2014.11.003

[11] El-Shirbeny, M.A., Alsersy, M.A.M., Saleh, N.H. and Abu-Taleb, K.A. (2015) Changes in Irrigation Water Consumption in the Nile Delta of Egypt Assessed by Remote Sensing. (In Press) https://doi.org/10.1007/s12517-015-2005-2

[12] Oki, T. and Kanae, S. (2006) Global Hydrological Cycles and World Water Resources. Science, 313, 1068-1072. https://doi.org/10.1126/science.1128845

[13] Stokcle, C.O. and Dugas, W.A. (1992) Evaluating Canopy Temperature-Based Indices for Irrigation Scheduling. Irrig. Sci., 13, 31-37.

[14] Idso, S.B., Jackson, R.D., Pinter, P.J., Reginato, R.J. and Hatfield, J.L. (1981) Normalizing the Stress Degree Day for Environmental Variability. Agric. Meteoro., 24, 4555. https://doi.org/10.1016/0002-1571(81)90032-7

[15] Jackson, R.D., Idso, S.B., Reginato, R.J. and Pinter, P.J. (1981) Canopy Temperature as a Crop Water Stress Indicator. Water Resources Research, 17, 1133. https://doi.org/10.1029/WR017i004p01133

[16] Jackson, R.D. (1982) Canopy Temperature and Crop Water Stress Index. Advances in Irrigation Journal, 1, 43-85. https://doi.org/10.1016/B978-0-12-024301-3.50009-5

[17] Reginato, R.J. (1983) Field Quantification of Crop Water Stress. ASAE, 26, 772-775. https://doi.org/10.13031/2013.34021

[18] Stegman, E.C. and Soderlund, M. (1992) Irrigation Scheduling of Spring Wheat Using Infrared Thermometry. ASAE, 35, 143-152. https://doi.org/10.13031/2013.28581

[19] Valor, E. and Caselles, V. (1996) Mapping Land Surface Emissivity from NDVI: Application to European, African and South American Areas. Remote Sensing of Environment, 57, 167-184. https://doi.org/10.1016/0034-4257(96)00039-9

[20] Norman, J., Kustas, W. and Humes, K. (1995) A Two-Source Approach for Estimating Soil and Vegetation Energy Fluxes from Observations of Directional Radiometric Surface Temperature. Agricultural and Forest Meteorology, 77, 263-293. 
https://doi.org/10.1016/0168-1923(95)02265-Y

[21] Kamble, B., Kilic, A. and Hubbard, K. (2013) Estimating Crop Coefficients Using Remote Sensing-Based Vegetation Index. Remote Sens., 5, 1588-1602. https://doi.org/10.3390/rs5041588

[22] Magliulo, V., d'Andria, R. and Rana, G. (2003) Use of the Modified Atmometer to Estimate Reference Evapotranspiration in Mediterranean Environments. Agricultural Water Management, 63, 1-14. https://doi.org/10.1016/S0378-3774(03)00098-2

[23] El-Shirbeny, M.A., Ali, A.M., Badr, M.A. and Bauomy, E.M. (2014b) Assessment of Wheat Crop Coefficient Using Remote Sensing Techniques. World Research Journal of Agricultural Sciences, 1, 12-17.

[24] Allen, R.G., Perrier, L.S., Raes, D. and Smith, M. (1998) Crop Evapotranspiration: Guidelines for Computing Crop Requirements. FAO Irrigation and Drainage (pp. 56). Rome, Italy.

[25] El-Shirbeny, M.A. and Abdellatif, B. (2017) Reference Evapotranspiration Borders Maps of Egypt Based on Kriging Spatial Statistics Method. International Journal of Geomate, 13, 1-8.

[26] Consoli, S. and Vanella, D. (2014) Mapping Crop Evapotranspiration by Integrating Vegetation Indices into a Soil Water Balance Model. Agricultural Water Management, 143, 71-81. https://doi.org/10.1016/j.agwat.2014.06.012

[27] Bausch, W.C. and Neale, C.M.U. (1989) Spectral Inputs Improve Corn Crop Coefficients and Irrigation Scheduling. Trans. ASAE, 326, 1901-1908.

[28] Bausch, W.C. (1993) Soil Background Effects on Reflectance-Based Crop Coefficients for Corn. Remote Sens. Environ., 46, 213-222.

https://doi.org/10.1016/0034-4257(93)90096-G

[29] Bausch, W.C. (1995) Remote Sensing of Crop Coefficients for Improving the Irrigation Scheduling of Corn. Agric. Water Manage., 27, 55-68. https://doi.org/10.1016/0378-3774(95)01125-3

[30] Tasumi, M., Allen, R.G. and Trezza, R. (2006) Calibrating Satellitebased Vegetation Indices to Estimate Evapotranspiration and Crop Coefficients. Proc. USCID Water Management Conf., Denver, Colo.

[31] Choudhury, B.J., Ahmed, N.U., Idso, S.B., Reginato, R.J. and Daughtry, C.S.T. (1994) Relations between Evaporation Coefficients and Vegetation Indices Studied by Model Simulations. Remote Sens. Environ., 50, 1-17. https://doi.org/10.1016/0034-4257(94)90090-6

[32] Neale, C.M.U., Bausch, W.C. and Heerman, D.F. (1989) Development of Reflectance-Based Crop Coefficients for Corn. Trans. ASAE, 326, 1891-1899.

[33] Rana, G. and Katerji, N. (2000) Measurement and Estimation of Actual Evapotranspiration in the Field under Mediterranean Climate: a Review. European Journal of Agronomy, 13, 125-153. https://doi.org/10.1016/S1161-0301(00)00070-8

[34] Er-Raki, S., Chehbouni, A., Guemouria, N., Duchemin, B., Ezzahar, J. and Hadria, R. (2007) Combining FAO-56 Model and Groundbased Remote Sensing to Estimate Water Consumption of Wheat Crops in Semi-Arid Regions. Agric. Water Manag., 87, 41-54. https://doi.org/10.1016/j.agwat.2006.02.004 
Submit or recommend next manuscript to SCIRP and we will provide best service for you:

Accepting pre-submission inquiries through Email, Facebook, LinkedIn, Twitter, etc. A wide selection of journals (inclusive of 9 subjects, more than 200 journals)

Providing 24-hour high-quality service

User-friendly online submission system

Fair and swift peer-review system

Efficient typesetting and proofreading procedure

Display of the result of downloads and visits, as well as the number of cited articles Maximum dissemination of your research work

Submit your manuscript at: http://papersubmission.scirp.org/

Or contact wjet@scirp.org 